\title{
KOMPETENSI GURU, BUDAYA ORGANISASI, DAN PELAYANAN TERHADAP KEPUASAN ORANG TUA MURID PADA SEKOLAH MENENGAH ATAS ISLAM HASMI BOGOR
}

Muslim

STAI Al Hidayah Bogor

\section{ABSTRAK}

Tulisan ini merupakan hasil penelitian yang difokuskan pada kompetensi guru, budaya organisasi dan pelayanan terhadap kepuasan orang tua siswa di SMA HASMI Bogor. Penulis mengidentifikasi masalah kepuasan orang tua siswa SMA Islam HASMI dengan beberapa faktor yang diduga mempengaruhinya, diantaranya adalah; a) kurangnya sarana komunikasi antara guru dan orang tua murid, b) adanya sarana dan prasarana yang dijanjikan belum dapat ditepati oleh manajemen, c) kurangnya kemampuan guru dalam proses KBM, d) lemahnya budaya kerjasama dari para karyawan, e) adanya guru yang kurang memahami karakteristik peserta didik dengan baik, f) kurangnya pengendalian dari aturan yang telah diberlakukan, g) organisasi belum menjadi perekat kalangan internal, h) tempat pelayanan yang kurang memadai, i) petugas pelayanan kurang handal dan responsif, dan j) kurangnya perhatian manajemen terhadap aduan, solusi, dan prioritas pelayanan. Metode penelitian ini adalah menggunakan metode kuantitatif dengan menggunakan model analisis satu jalur (Path Analisys). Dalam menganalisa data hasil kuesioner digunakan alat bantu komputer dengan program SPSS versi 19,0. Tempat penelitian di SMA Islam HASMI Boarding School di Kecamatan Tamansari Bogor dengan resonden berjumlah 83 orang. Hasil penelitian menunjukkan bahwa variabel kompetensi guru berpengaruh nyata dan signifikan terhadap kepuasan dengan nilai signifikansi sebesar 0,001. Besarnya pengaruh variabel kompetensi guru terhadap kepuasan orang tua murid pada SMA Islam HASMI adalah 0,430. Variabel budaya organisasi tidak berpengaruh nyata terhadap kepuasan dengan nilai signifikansi sebesar 0,078. Besarnya pengaruh variabel budaya organisasi terhadap kepuasan orang tua murid pada SMA Islam HASMI adalah 0,273 . Sedangkan variabel pelayanan tidak berpengaruh terhadap kepuasan dengan nilai sebesar 0,289. Besarnya pengaruh variabel budaya organisasi terhadap kepuasan orang tua murid pada SMA Islam HASMI adalah 0,143. Adapun variabel kompensi guru, budaya organisasi, dan pelayanan secara simultan berpengaruh nyata dan signifikan sebesar $63,3 \%$ terhadap kepuasan orang tua murid pada SMA Islam HASMI.

Kata Kunci: Kompetensi guru, budaya organisasi, pelayanan, kepuasan.

\section{PENDAHULUAN}

Kepuasan konsumen dalam mendapatkan barang atau jasa yang digunakan berupa kenyamanan, keamanan, informasi yang benar, jelas dan jujur, mendapat kompensasi atau ganti rugi yang diakibatkan oleh adanya barang atau jasa yang tidak sesuai dengan yang dijanjikan, dan 
mendapatkan advokasi dalam upaya penyelesaian sengketa perlindungan konsumen, merupakan hak dan kebutuhan yang senantiasa dituntut dan diperjuangkan. Interaksi antar manusia dalam kehidupan secara umum dan dalam dunia usaha khususnya, sering kali didapati adanya perseteruan antara satu pihak dengan pihak lain atau antara pihak produsen dengan konsumennya. Penyebab yang paling dominan dalam perseteruan tersebut,adalah karena adanya ketidakpuasan konsumen terhadap layanan yang diberikan. Untuk meminimalisir perselisihan yang terjadi, pemerintah selaku penyelenggara negara membuat aturan-aturan yang dapat dijadikan acuan oleh semua pihak dalam berinteraksi dan bertransaksi antara pihak produsen sebagai pelaku dalam dunia usaha dan pihak konsumen sebagai pengguna produk dari barang atau jasa, seperti telah diatur dalam Pasal 4 Undang-undang Perlindungan Konsumen No. 8 Tahun 1999.

Terkait masalah kepuasan konsumen atau pelanggan seperti telah disinggung di atas, dapat pula terjadi dalam dunia pendidikan. Pendidikan sebagai kebutuhan primer dalam kehidupan modern dan telah diamanatkan dalam pembukaan serta batang tubuh UUD 1945, adalah sebuah produk dalam bidang jasa yang ditelurkan dari para penyelenggaranya. Dalam Peraturan Pemerintah Republik Indonesia No. 17 Tahun 2010, dikatakan bahwa penyelenggara pendidikan dalam hal ini adalah pemerintah pusat, pemerintah provinsi, pemerintah kabupaten/kota, penyelenggara satuan pendidikan yang didirikan masyarakat dan satuan atau program pendidikan.

Sekolah Menengah Atas (SMA) Islam HASMI yang berada dalam naungan Ormas Islam HASMI dan Yayasan Islam Al-Huda Bogor Indonesia pada hakekatnya merupakan salah satu dari organisasi pendidikan yang telah dan senantiasa berupaya melakukan tugas dan fungsinya dalam penyelenggaraan pendidikan dengan sebaik-baiknya. Namun dalam melaksanakan tugas dan fungsinya tersebut dirasa belum sepenuhnya terlaksana, karena banyaknya berbagai kendala yang dihadapi, seperti. kurangnya kompetensi guru atau tenaga pendidik, pelayanan tenaga kependidikan yang kurang sesuai dengan apa yang diharapkan para konsumennya, sarana dan prasarana yang kurang memadai dan kendalakendala lain yang ada. Untuk itu, manajemen sekolah Islam HASMI terus berusaha meningkatkan pelayanan yang prima kepada peserta didik secara 
khusus maupun pihak orang tua murid pada umumnya dengan mengacu kepada (8) delapan butir standarisasi yang telah ditetapkan oleh PERMENDIKNAS No. 63 Tahun 2009, tentang Sistem Penjaminan Mutu pendidikan. Diharapkan dengan terpenuhinya delapan butir standarisasi penjaminan mutu pendidikan, dapat menambah mutu pendidikan yang diberikan oleh SMA Islam HASMI. Dengan demikian, diharapkan hal ini dapat menambah pula kepuasan peserta didik secara khusus dan orangtua murid pada umumnya selaku konsumen kepada SMA Islam HASMI.

Dari beragam uraian yang telah disebutkan, maka penulis berasumsi bahwa faktor-faktor yang dapat mempengaruhi meningkatnya kepuasan orang tua murid kepada SMA Islam HASMI di antaranya adalah dengan meningkatkan kompetensi guru, budaya organisasi, dan kualitas pelayanan. Menurut penulis, pada dasarnya penelitian dalam rangka mengetahui tingkat kepuasan orangtua murid penting untuk dilakukan, karena posisi orangtua merupakan bagian dari konsumen atau pelanggan selain siswa atas pelayanan jasa yang diberikan oleh sekolah. Untuk itu penelitian ini ditujukan guna mengetahui bagaimana pengaruh kompetensi guru, budaya organisasi, dan kualitas pelayanan terhadap tingkat kepuasan orangtua SMA Islam HASMI.

Dari uraian yang telah disebutkan di atas, maka penulis mencoba untuk merumuskan beberapa permasalahan berikut; 1) Bagaimana pengaruh kompetensi guru terhadap kepuasan orang tua murid setelah memasukkan putra-putri mereka di SMA Islam HASMI? 2) Bagaimana pengaruh budaya organisasi terhadap kepuasan orang tua murid setelah memasukkan putraputri mereka di SMA Islam HASMI? 3)Bagaimana pengaruh pelayanan terhadap kepuasan orang tua murid setelah memasukkan putra-putri mereka di SMA Islam HASMI? 4) Bagaimana pengaruh kompetensi guru, budaya organisasi, dan pelayanan secara simultan terhadap kepuasan orangtua murid setelah memasukkan putra-putri mereka di SMA Islam HASMI?

\section{TINJAUAN TEORITIS}

\section{Kepuasan}

Menurut Day dalam Tse dan Wilton (1988) dalam Tjiptono (2008:24) mengatakan bahwa kepuasan atau ketidakpuasan pelanggan adalah respon 
pelanggan terhadap evaluasi ketidaksesuaian (disconfirmation) yang dirasakan antara harapan sebelumnya (atau norma kinerja lainnya) dan kinerja aktual produk yang dirasakan setelah pemakaiannya. Wilkie (1990) dalam Tjiptono (2008, h. 24) mendefinisikan sebagai suatu tanggapan emosional pada evaluasi terhadap pengalaman konsumsi suatu produk atau jasa. Menurut Engel, et.al (1990) dalam Tjiptono (2008, h. 24) menyatakan bahwa kepuasan pelanggan merupakan evaluasi purnabeli di mana alternatif yang dipilih sekurang-kurangnya sama atau melampaui harapan pelanggan. Konsep dasar dari kepuasan konsumen dapat ditunjukkan oleh gambar berikut.

Gambar 1 konsep kepuasan pelanggan

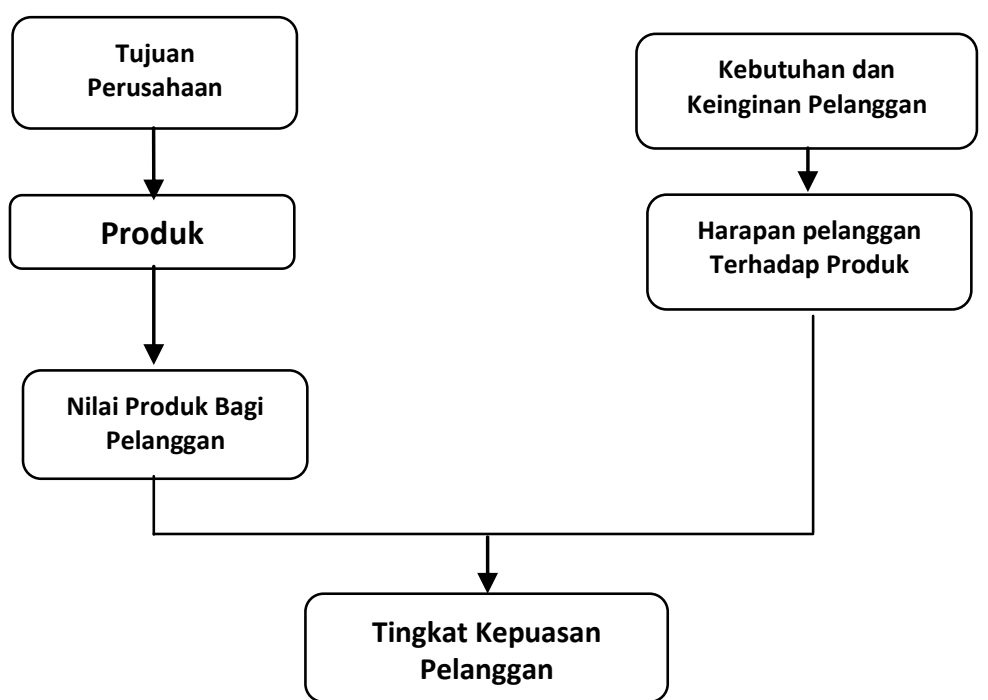

Sumber: Buku Strategi Pemasaran (Tjiptono; 2008)

\section{Kompetensi Guru}

Menurut Unang Wahidin (2015, h.103), kompetensi mengacu pada kemampuan melaksanakan sesuatu yang diperoleh melalui pendidikan dan pelatihan. Selanjutnya dia mengatakan, untuk meningkatkan kompetensi ini tentu diperlukan upaya pendidikan dan pelatihan yang optimal dan berkualitas. Sementara itu, Payong (2011, h. 17) mengatakan bahwa ada perbedaan antara kualifikasi dan kompetensi. Kualifikasi merujuk kepada syarat formal yang harus diselesaikan melalui aktivitas akademik tertentu dan itu dibuktikan dengan adanya ijasah atau sertifikat yang dimiliki setelah yang bersangkutan menyelesaikan studi pada jenjang pendidikan tertentu. Undang-undang No. 14 tahun 2005 mempersyaratkan bahwa guru pada 
semua jenjang pendidikan haruslah memiliki kualifikasi akademik minimal S1 atau D-IV. Kualifikasi bersifat statis, artinya pengakuan terhadap kemampuan akademik seseorang yang dibuktikan dengan pemberian ijazah atau sertifikat tidak berubah sejauh yang bersangkutan menyandang gelar akademik yang sesuai. Orang yang menyandang gelar S1 dianggap sebagi sarjana dan layak untuk memasuki bidang pekerjaan tertentu. Sedangkan kompetensi adalah kemampuan yang dimiliki seseorang, akibat dari pendidikan maupun pelatihan, atau pengalaman belajar informal tertentu yang didapat, sehingga menyebabkan seseorang dapat melaksanakan tugas tertentu dengan hasil yang memuaskan (Jurnal Edukasi Islam,Vol. 5 No. 09 hal. 1231-1250).

Menurut PERMENDIKNAS No. 16 Tahun 2007 Tentang Standar Kualifikasi Akademik dan Kompetensi Guru disebutkan bahwa macam kompetensi yang harus dimiliki oleh tenaga guru antara lain; kompetensi pedagogik, kompetensi kepribadian, kompetensi professional, dan kompetensi sosial yang diperoleh melalui pendidikan profesi. Keempat kompetensi tersebut terintegrasi dalam kinerja guru.

\section{Budaya Organisasi}

Menurut Edward B. Tylor dalam Achmad Sobirin (2007: h. 52) bahwa yang dimaksud dengan kultur atau peradaban adalah kompleksitas menyeluruh yang terdiri dari pengetahuan, keyakinan, seni, moral, hukum, adat kebiasaan dan berbagai kapabilitas lainnya serta kebiasaan apa saja yang diperoleh seorang manusia sebagai bagian dari sebuah masyarakat. Didin dan Hendri Tanjung (2003: h. 59) mengatakan bahwa budaya adalah segala nilai, pemikiran, serta simbol yang mempengaruhi perilaku, sikap, kepercayaan serta kebiasaan seseorang dan masyarakat.

Dari beberapa pengertian tentang budaya yang telah dijelaskan, dapat dikatakan bahwa budaya merupakan keyakinan, ilmu, kerangka fikir, dan nilai-nilai yang mempengaruhi perilaku seseorang atau sekelompok orang dalam berinteraksi atau bergaul. Hal ini menunjukkan bahwa hubungan budaya dengan manusia seperti dua sisi mata uang, budaya diciptakan oleh manusia, kemudian manusia hidup dan berinteraksi dengan kebudayaan 
yang diciptakannya tersebut (Jurnal Edukasi Islam, Vol. 5 No.10: 13111336).

Untuk itu, budaya yang tercipta dan ada dalam lingkungan organisasi disebut dengan budaya organisasi, karena ia merupakan keyakinan, ilmu, kerangka fikir dan nilai-nilai yang dihasilkan atau tercipta dari sekumpulan orang dalam satu wadah yang saling bekerjasama untuk mencapai tujuan yang telah disepakati bersama.

\section{Pelayanan}

Pasuraman et.al (1988) dalam Prianto (2008: h. 1063-1064) mendefinisikan kualitas layanan sebagai perbedaan antara persepsi pelanggan tentang layanan yang baik dengan pemenuhan harapan mereka tentang layanan yang berkualitas yang mampu disediakan oleh penyedia layanan. Ada lima dimensi yang dapat digunakan sebagai indikator untuk menyatakan kegiatan layanan yang berkualitas, yang mencakup: a) dimensi tangibles; yang dilihat dari tampilan fasilitas fisik, perlengkapan, personil dan sarana komunikasi. Dalam konteks persekolahan, hal ini akan terlihat dari ketersediaan bangunan yang menarik, peralatan belajar yang mutakhir, dan penampilan staf yang meyakinkan; b) dimensi reliabilitas; yaitu kemampuan untuk menampilkan bentuk layanan yang akurat; c) dimensi responsiveness; yaitu kesediaan untuk membantu pelanggan dan menyediakan layanan yang diinginkan; d) dimensi assurance; kecakapan, keahlian, dan kesantunan para staf yang ditunjukkan dengan kesediaan memberikan layanan dengan penuh percara diri sehingga mampu menumbuhkan kepercayaan kepada pelanggan; dan e) dimensi empathy; peduli dan penuh perhatian kepada pelanggan. Granoso (1990) \& Parasuratman et.al (1988) dalam Gandolfo (2010) mengatakan kualitas pelayanan dan kepuasan pelangganmerupakan factor penting untuk keberhasilan bisnis.

Berdasarkan pendapat di atas, dapat diartikan bahwa kualitas pelayanan adalah karakteristik pelayanan yang terdiri dari unsur tangibel, realibility, responsiveness, assurance, dan empathy. Dimensi tangible dapat pula dijabarkan lagi menjadi indikator-indikator berikut: a) Ruang tunggu pelayanan, b) Loket pelayanan, dan c) Penampilan petugas pelayanan. Sedangkan dimensi reliability dijabarkan lagi menjadi indikator-indikator: a) 
Keandalan petugas dalam memberikan informasi pelayanan, b) Keandalan petugas dalam melancarkan prosedur pelayanan, dan c) Keandalan petugas dalam memudahkan teknis pelayanan. Dimensi responsiveness dijabarkan lagi menjadi indikator-indikator:a) Respon petugas pelayanan terhadap keluhan warga, b) Respon petugas pelayanan terhadap saran warga, dan c) Respon petugas pelayanan terhadap kritikan warga. Dimensi assurance dijabarkan menjadi indikator-indikator: a) Kemampuan administrasi petugas pelayanan, b) Kemampuan teknis petugas pelayanan, c) Kemampuan sosial petugas pelayanan. Dimensi emphaty dijabarkan lagi menjadi beberap indikator: a) Perhatian petugas pelayanan, b) Kepedulian petugas, c) Keramahan petugas pelayanan.

\section{HASIL PENELITIAN DAN PEMBAHASAN}

Menurut penelitian yang dilakukan oleh Ratih Hardiyati dalam skripsinya yang berjudul "Analisis Pengaruh Kualitas Pelayanan Terhadap Kepuasan Konsumen Menggunakan Jasa Penginapan (Villa) Argowisata Kebun Teh Pagilaran" (2010). yang bertujuan untuk menganalisis pengaruh kualitas pelayanan dengan seluruh indikator yang ada didalamnya seperti; a) tangible (bukti fisik), b) reliability (kehandalan), responsivness (tanggapan), assurance (jaminan), dan empathy (empati) terhadap kepuasan konsumen dalam menggunakan jasa penginapan argowisata kebun teh pagilaran ini menunjukkan hasil yang cukup memuaskan. Hasil analisis menunjukkan bahwa kualitas pelayanan yang diberikan oleh villa agrowisata kebun teh pagilaran secara umum sudah baik. Hal ini dapat ditunjukkan tanggapan kepuasan yang tinggi dari responden terhadap kondisi masing-masing variabel penelitian. Dari hasil tersebut selanjutnya diperoleh hasil bahwa variabel kualitas pelayanan dengan kelima dimensinya memiliki pengaruh positif dan signifikan terhadap kepuasan konsumen. Hal ini dikarenakan bahwa dengan pemberian pelayanan yang berkualitas, maka hal tersebut akan menciptakan kepuasan bagi konsumen.

Konsep dasar dari pemilihan topik permasalahan yang penulis tuangkan dalam penenlitian ini, didasari oleh keingintahuan dan responsibility penulis terhadap eksistensi dan perkembangan SMA Islam HASMI. Dengan melihat dokumentasi yang ada di SMA Islam HASMI dan berdasarkan teori- 
teori kepuasan yang penulis dapatkan melalui berbagai literatur yang ada, maka penulis mencoba merumuskan permasalah-permasalahan yang penulis duga dihadapi oleh SMA Islam HASMI dengan harapan hal tersebut dapat membantu menyelesaikan sebagian dari permasalahan yang dihadapi oleh SMA Islam HASMI. Di antaranya adalah dengan melalui perbaikan kompetensi guru, budaya organisasi, dan pelayanan. Dengan kompetensi guru yang terus ditingkatkan, kemudian pengendalian budaya organisasi yang optimal tentu akan membantu meningkatkan pelayanan seluruh karyawan dalam melakukan pelayanan jasa pendidikan yang prima kepada para pelanggan. Maka secara langsung hal ini dapat meningkatkan kepuasan orang tua murid sebagai konsumen terhadap SMA Islam HASMI, maka penulis mencoba menggambarkan skema kerangka berfikir dalam gambar berikut;

Gambar 2 Skema Kerangka Berfikir

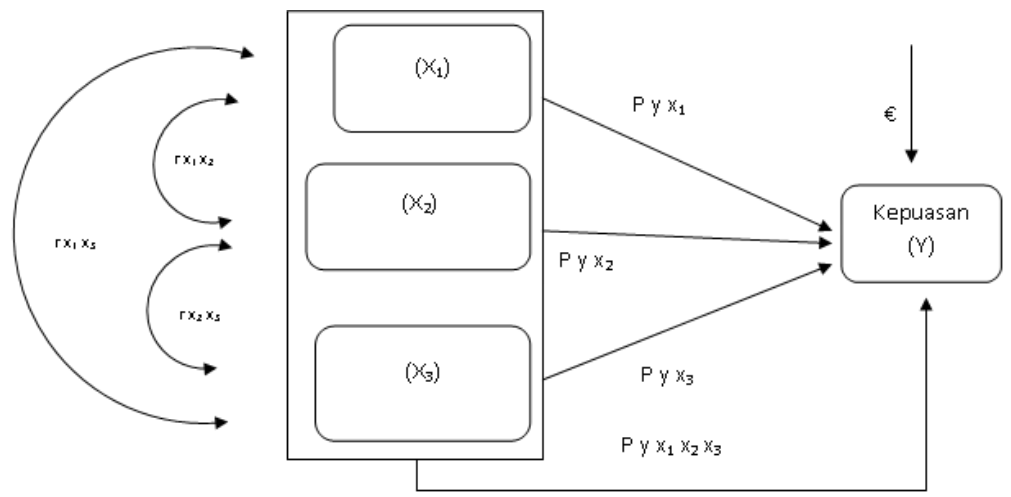

\section{Keterangan:}

$\mathrm{X}_{1}=$ Kompetensi Guru

$\mathrm{X}_{2}=$ Budaya Organisasi

$\mathrm{X}_{3}=$ Pelayanan

$\mathrm{Y}=$ Kepuasan

Berdasarkan kajian pustaka dan teori-teori tentang penelitian kepuasan konsumen/pelanggan yang relevan terhadap penelitian yang penulis lakukan, serta adanya dasar kerangka berfikir di atas, maka hipotesa dalam penelitian ini dapat diuraikan sebagai berikut; 1) Adanya pengaruh kompetensi guru terhadap kepuasan orangtua murid kepada SMA Islam HASMI, 2) Adanya pengaruh budaya organisasi terhadap kepuasan orangtua murid kepada SMA Islam HASMI, 3) Adanya pengaruh pelayanan terhadap 
kepuasan orangtua murid kepada SMA Islam HASMI, dan 4) Ada pengaruh kompetensi guru, budaya organisasi, dan pelayanan secara simultan terhadap kepuasan orangtua murid kepada SMA Islam HASMI.

\section{METODOLOGI}

Dalam melakukan penelitian ini, penulis memilih jenis penelitian kuantitatif dengan metode studi kasus di sekolah menengah atas (SMA) Islam HASMI. Orangtua/wali murid di sekolah menengah atas (SMA) Islam HASMI berjumlah delapan puluh tiga (83) orang, maka dalam penelitian ini penulis melakukan studi pupulasi atau studi sensus, yaitu penelitian kepada seluruh subyek yang termasuk dalam penelitian, dengan menyebar kuesioner kepada seluruh orang tua/wali murid sekolah menengah atas (SMA) Islam HASMI tanpa membedakan status mereka dalam keluarga, apakah ia seorang ayah, ibu, atau wali dengan status lainnya yang terkait dengan tali kekerabatan. Kuesioner yang telah diisi oleh responden dan kembali kepada penulis hanya berjumlah 73 orangtua/wali murid. analisis data yang penulis lakukan dalam penelitian ini melalui metode statistik deskriptif dengan pendekatan model analisis jalur (Path Analysis Models) meliputi beberapa hal berikut:

\section{Uji Model Koefisien Determinasi $\left(\mathbf{R}^{2}\right)$}

Koefisien determinasi pada dasarnya mengukur bagaimana kemampuan model dalam menerangkan variasi variabel independen. Nilai koefisien determinasi adalah antara nol dan satu. Nilai koefisien determinasi $\left(R^{2}\right)$ yang kecil berarti kemampuan variabel-variabel independen dalam menjelaskan variasi variabel dependen amat terbatas. Nilai yang mendekati satu berarti variabel-variabel independen memberikan hampir semua informasi yang dibutuhkan untuk memprediksi variasi variabel dependen (Ghozali, 2005).

\section{Uji F}

Priyatno (2008:82) mengatakan, Uji F digunakan untuk mengetahui variabel bebas secara bersama-sama mempunyai pengaruh secara signifikan terhadap variabel terikat. Atau untuk mengetahui apakah model regresi dapat digunakan untuk memprediksi variabel terikat atau tidak. 
Signifikan berarti hubungan yang terjadi dapat berlaku untuk populasi. Tingkat signifikansi menggunakan $\alpha=5 \%$ atau 0,05 .

\section{HASIL PENELITIAN}

Yayasan Islam Al-Huda yang telah disahkan oleh akta Notaris dan Pejabat Pembuat Akta Tanah dengan AKTA Nomor 183 Tanggal 29 April 1998 berkedudukan di Bogor Kecamatan Ciomas Desa Sukamulya RT 05/04 Jalan Pintu Ledeng No. 34 mempunyai maksud dan tujuan untuk berperan aktif dalam usaha membantu pemerintah melaksanakan pembangunan bangsa Indonesia dalam bidang sosial, kesehatan, dan pendidikan, berupa pembinaan kepada sosok muslim yang beriman dan bertaqwa serta beramal sholeh, mewujudkan kesatuan umat, dan meningkatkan taraf kehidupan sosial dan ekonomi. Untuk mencapai tujuan di atas, maka salah satu jalan yang ditempuh yayasan adalah dengan mendirikan lembaga pendidikan dari TK hingga Perguruan Tinggi (lihat Jurnal Edukasi Islam,Vol. 4 No.07. hal. 787-805), dan di antaranya adalah SMA Islam HASMI yang dimulai pada tahun ajaran 2010/2011.

Adapun Sekolah Menengah Atas (SMA) Islam HASMI yang menjadi obyek dalam penelitian ini berlokasi di J. Raya Cimanglid, Gg. Purnama Ciapus Desa Sukamantri Kec. Tamansari Kab. Bogor. No. Telp. 0251 9753852 dengan alamat www.hasmi-islamicschool.com dan alamat Email: smaislamhasmi@yahoo.co.id memiliki izin operasional No.421.3/17-Dikmen 4 April 2011 dan nomor statistik sekolah 302020231 162. SMA ISLAM HASMI mulai dioperasikan pada tahun ajaran 2010/2011 dengan membuka hanya satu kelas untuk siswa putri.

Visi SMA ISLAM HASMI "Mewujudkan Generasi Robbani Yang Mandiri dan Berprestasi dibidang Imtak dan Iptek". Untuk mewujudkan visi yang telah dicanangkan ini, manajemen SMA Islam HASMI telah menetapkan tujuh indikator, di antaranya adalah; 1) Unggul dalam peningkatan iman dan takwa menurut pemahaman ahlussunnah waljama'ah, 2) Unggul dalam peningkatan nilai Ujian Nasional (UN), 3) Unggul dalam berbagai lomba intra dan ekstrakurikuler, 4) Unggul dalam menghafal dan mengamalkan nilai-nilai yang terkandung di dalam Al-Qur'an, 5) Unggul dalam bahasa Arab dan Inggris secara aktif dan fasif, 6) Terampil dalam memanfaatkan teknologi 
informasi dan komunikasi, dan 8) Lingkungan sekolah yang Islami, bersih dan sehat.

Adapun misi SMA ISLAM HASMI yaitu;1) Melaksanakan kegiatan pembinaan keagamaan bagi warga sekolah secarta rutin dan berkesinambungan, 2) Melaksanakan proses pembelajaran yang efektif dan efisien bagi semua guru dan peserta didik, 3) Menciptakan semangat berpretasi dan berkarya bagi warga sekolah, 4) Meningkatkan pembinaan dan pelatihan guru dan staf usaha, 5) Melengkapi sarana dan prasarana pembelajaran, 6) Meningkatkan pelaksanaan kegiatan ekstrakurikuler, 6) Melengkapi sarana ekstrakurikuler, 7) Meningkatkan pembinaan menghafal al-Qur'an serta menerapkan nilai-nilai yang terkandung di dalamnya secara terprogram, 8) Membiasakan warga sekolah untuk menggunakan bahasa Arab dan Inggris dalam berkomunikasi sehari-hari, dan 9) Membiasakan peserta didik memanfatkan tekonogi informasi dan komunikasi untuk belajar dan berdakwah.

Peserta didik yang direkrut sebagai siswa SMA ISLAM HASMI adalah mereka yang berdomisili di sekitar wilayah Bogor dan sekitarnya serta pernah mengikuti pendidikan di Sekolah Menengah Pertama (SMP), baik SMP umum, SMPIT maupun Madrasah Tsanawiyah. Peserta didik yang direkrut tidak hanya terfokus dari wilayah Kabupaten dan Kota Bogor, namun juga diharapkan dari daerah-daerah luar Bogor.

Gambar 3 Struktur Organisasi SMA ISLAM HASMI

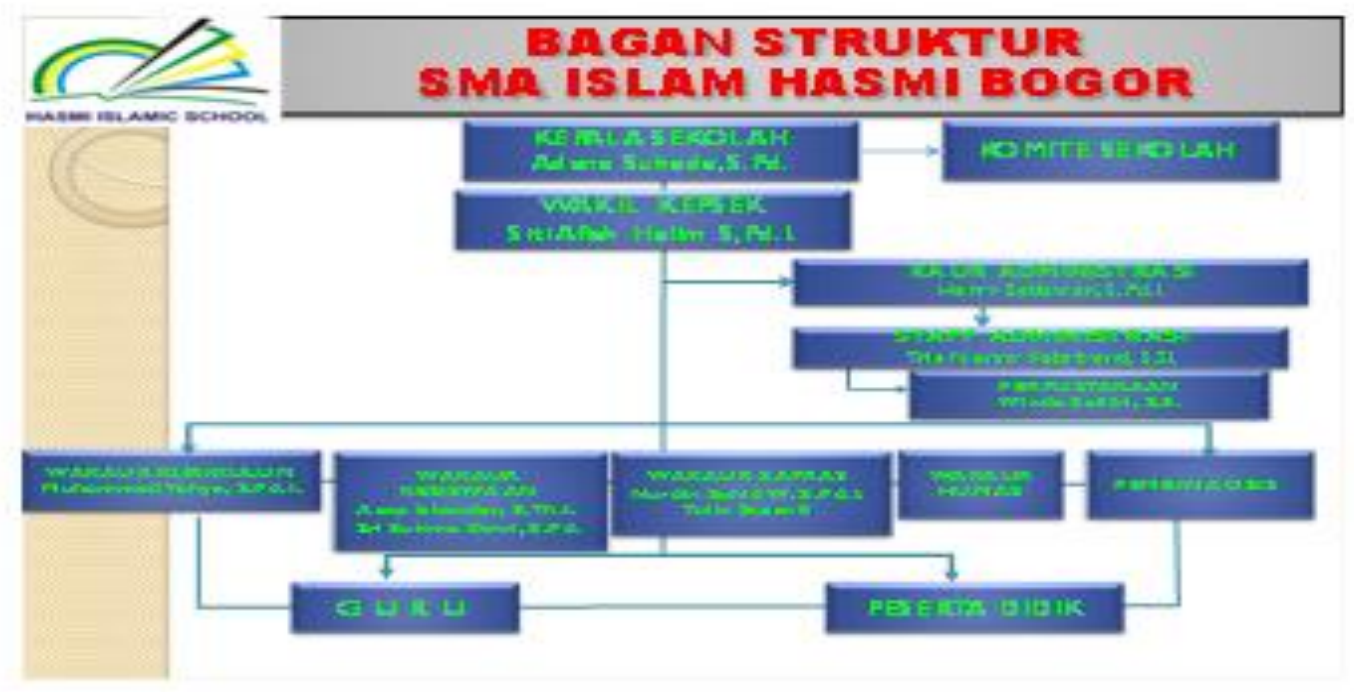

Analisis Penelitian 


\section{Uji Validitas}

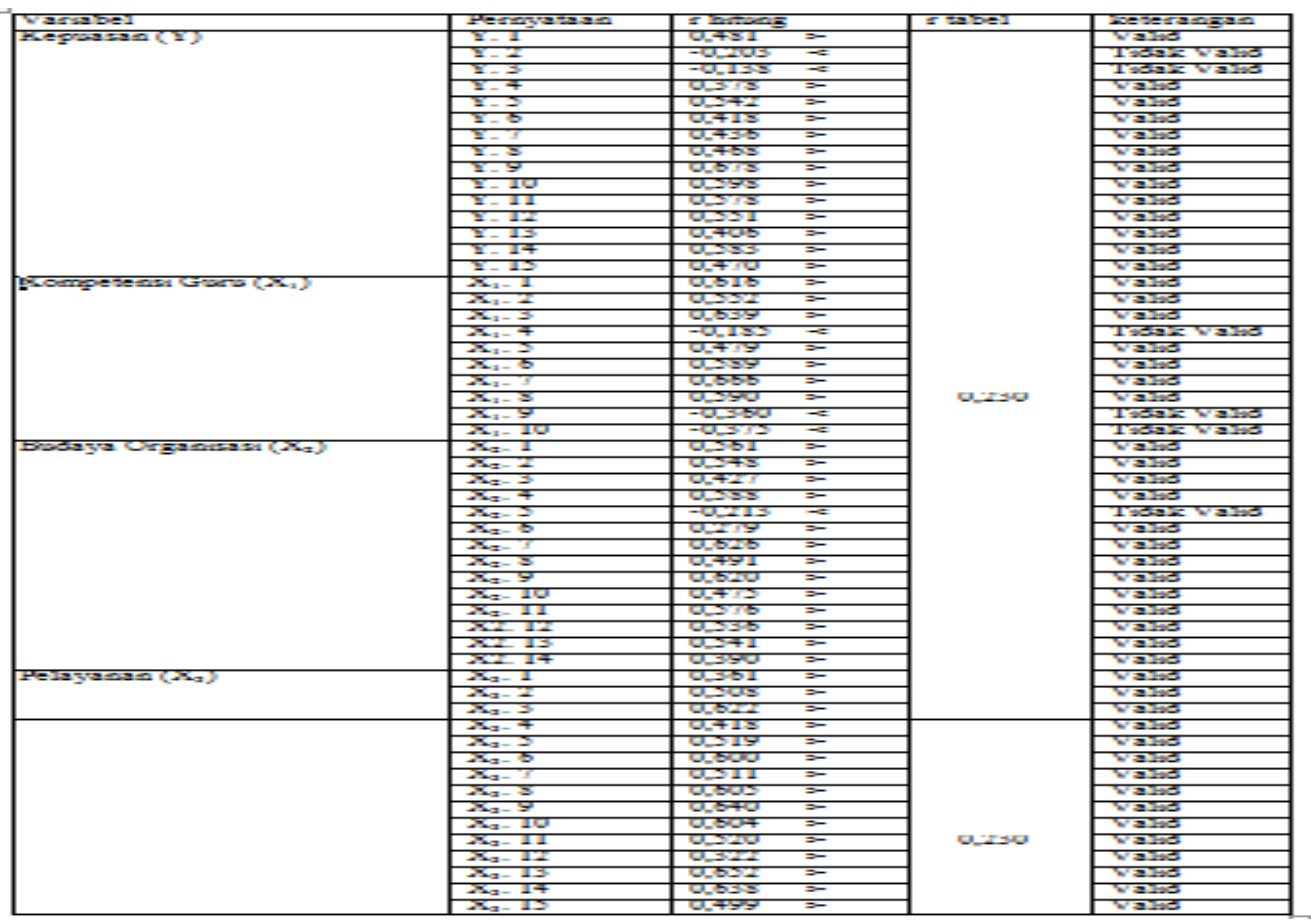

Valid tidaknya sebuah indikator pernyataan/pertanyaan dinilai berdasarkan nilai $r$ hitung yang didapat lantas dibandingkan dengan nilai $r$ tabel, apabila; 1) Nilai $r$ hitung lebih kecil dari $r$ tabel maka item pernyataan/pertanyaan tidak berkorelasi secara signifikan terhadap skor total kemudian item pernyataan/pertanyaan dinyatakan tidak valid, 2) Nilai r hitung lebih besar dari $r$ tabel maka item pernyataan/pertanyaan berkorelasi secara signifikan terhadap skor total kemudia item pernyataan/pertanyaan tersebut dinyatakan valid.

Berdasarkan hasil dari uji validitas di atas bahwa indikator pada variabel $X_{1}$ (Kompetensi Guru) pada pernyataan/pertanyaan 4, 9, dan 10 tidak valid maka tidak diikutsertakan lagi pada pembahasan selanjutnya. Dari 7 penyataan/pertanyaan (tanpa pernyataan/pertanyaan 4, 9, dan 10) seluruh pernyataan/pertanyaan untuk variabel $X_{1}$ (Kompetensi Guru) keseluruhannya valid. Untuk variabel $X_{2}$ (Budaya Organisasi) pada pernyataan/pertanyaan 5 tidak valid maka tidak diikutsertakan lagi pada analisis selanjutnya. Dari 13 pernyataan/pertanyaan (tanpa pernyataan/pertanyaan 5) seluruh pernyataan/pertanyaan untuk variabel $\mathrm{X}_{2}$ (Budaya Organisasi) keseluruhannya valid. Pada variabel $X_{3}$ (Pelayanan) seluruh indikator pernyataan/pertanyaan untuk variabel $X_{3}$ (pelayanan) valid. Pada variabel $Y$ (Kepuasan) pada pernyataan/pertanyaan 2 dan 3 tidak valid maka tidak 
diikutsertakan lagi pada analisis selanjutnya. Dari 13 pernyataan/pertanyaan (tanpa pernyataan/pertanyaan 2 dan 3) seluruh indikator pernyataan/pertanyaan untuk variabel Y (Kepuasan) valid.

\section{Uji Reliabilitas}

Uji Reliabilitas dilakukan untuk mengetahui apakan instrumen (alat ukur) dapat dipercaya atau konsisten. Pengujian Reliabilitas dalam penelitian ini dilakukan dengan menggunakan koefisien Cronbach's Alpha Masyhudzulhak (2012:80) Alpha Cronbach's akan dinyatakan layak jika batasnya adalah 0,60. Ghozali (2005) apabila nilai cronbach's Alpha $>0,60$ maka variabel bisa dikatakan sudah reliabel.

Tabel 1. Tingkat Pengukuran Variabel

\begin{tabular}{|c|c|c|c|}
\hline No & Tingkat Pengukuran & Jumlah & Cronbach's Alpha \\
\hline 1 & Kompetensi Guru & 7 & 0,923 \\
\hline 2 & Budaya Organisasi & 13 & 0,922 \\
\hline 3 & Pelayanan & 15 & 0,924 \\
\hline 4 & Kepuasan & 13 & 0,921 \\
\hline
\end{tabular}

Berdasarkan data tabel 12 yang menunjukkan bahwa hasil Cronbach's Alpha untuk variabel Kompetensi Guru 0,923 > 0,60 berarti reliabel, untuk variabel Budaya Organisasi 0,922 > 0,60 berarti reliabel, untuk variabel Pelayanan 0,924 > 0,60 berarti reliabel, dan untuk variabel Kepuasan 0,921 $>0,60$ berarti reliabel.

Untuk dapat mengoptimalkan hasil yang akan diketahui dalam penelitian ini, maka perlu kiranya dilakukan analisis berdasarkan kaidahkaidah ilmiah penelitian. Berdasarkan kerangka berfikir secara ringkas hubungan antar variabel-varibael dapat diperhatikan melalui gambar berikut: 
Gambar 4 Model Diagram Jalur Menurut Paradigma Model

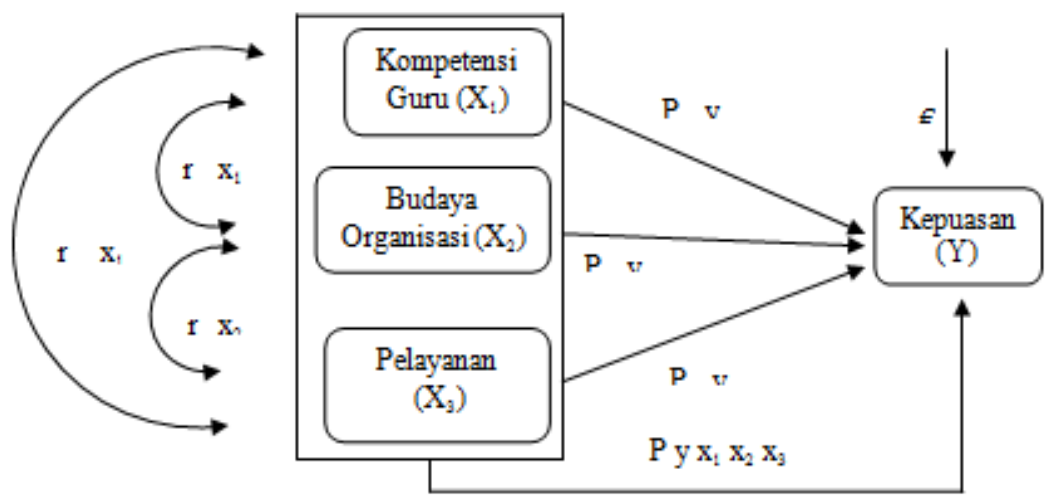

Keterangan

$\mathrm{X}_{1}$ : Kompetensi Guru

$\mathrm{X}_{2}$ : Budaya Organisasi

$\mathrm{X}_{3}$ : Pelayanan

Y : Kepuasan

Persamaan struktur: $Y=P_{y x 1} X_{1}+P_{y x 2} X_{2}+P_{y x 3} X_{3}+P_{y} €$

Analisis Pengaruh variabel Kompetensi Guru, Budaya Organisasi, dan Pelayanan Terhadap Kepuasan OrangTua Murid Pada SMA Islam HASMI

Persamaan struktur yang sesuai dengan model diagram jalur berdasarkan paradigma diagram jalur adalah.

Persamaan Struktur:

$$
Y=P_{y x 1} X_{1}+P_{y x 2} X_{2}+P_{y x 3} X_{3}+P_{y} €
$$

\section{Uji model koefisien determinasi $\left(\mathbf{R}^{2}\right)$}

Nilai koefisien determinasi adalah antara nol dan satu. Nilai Koefisien Determinasi $\left(R^{2}\right)$ yang kecil berarti kemampuan variabel-variabel independen dalam menjelaskan variable-variabel dependen amat terbatas. Nilai yang mendekati satu berarti variabel-variabel independen memberikan hampir semua informasi yang dibutuhkan untuk memprediksi variasi variabel dependen (Ghozali, 2005).

Untuk dapat mengetahui pengaruh variabel kompetensi guru, budaya organisasi, dan pelayanan terhadap kepuasan maka dilakukan analisis dengan menggunakan analisis regresi berganda. Adapun hasil perhitungan 
dari analisis regresi berganda dapat dilihat dalam model summary pada tabel berikut:

Tabel 2. Model Summary

Model Summary

\begin{tabular}{|c|c|c|c|c|c|}
\hline Model & $\mathrm{R}$ & $\mathrm{R}$ Square & Adjusted R Square & $\begin{array}{c}\text { Std. Error of the } \\
\text { Estimate }\end{array}$ & Durbin-Watson \\
\hline 1 & $.796^{\mathrm{a}}$ & .633 & .617 & .35691 & 1.860 \\
\hline
\end{tabular}

a. Predictors: (Constant), Pelayanan, Kopetensi Guru, Budaya Organisasi

b. Dependent Variable: Kepuasan

Output dari analisis regresi di atas diperoleh hasil bahwa besarnya angka $R$. Squer $\left(R^{2}\right)$ adalah 0,633 . besaran angka ini digunakan untuk melihat pengaruh kompetensi guru, budaya organisasi, dan pelayanan secara simultan atau bersama-sama terhadap kepuasan dengan menghitung koefisien determinasinya. Adapun rumus koefisien determinasi adalah sebagai berikut:

$$
\begin{aligned}
\mathrm{KD} & =\mathrm{R}^{2} \times 100 \% \\
& =0,633 \times 100 \%=63,3 \%
\end{aligned}
$$

Berarti pengaruh kompetensi guru, budaya organisasi, dan pelayanan terhadap kepuasan sebesar 63,3 \%, sedangankan sisanya 36,7 \% (100\% $63,3 \%$ ) dipengaruhi oleh model lain yang tidak termasuk dalam penelitian ini.

\section{Uji F}

Untuk dapat mengetahui apakah model dalam penelitian ini signifikan atau tidak signifikan maka dilakukan uji f. Berdasarkan hasil analisis regresi didapati model seperti pada tabel Anova berikut ini.

\begin{tabular}{|c|c|c|c|c|c|c|}
\hline \multicolumn{7}{|c|}{ ANOVA $^{\mathrm{D}}$} \\
\hline & Model & Sum of Squares & $d f$ & Mean Square & $F$ & Sig. \\
\hline 1 & Regression & 15.185 & 3 & 5.062 & 39.736 & $.000^{\mathrm{a}}$ \\
\hline & Residual & 8.790 & 69 & .127 & & \\
\hline & Total & 23.975 & 72 & & & \\
\hline
\end{tabular}

Tabel 3. Model Anova

a. Predictors: (Constant), Pelayanan, Kopetensi Guru, Budaya Organisasi

b. Dependent Variable: Kepuasan

Masyhudzulhak (2012:117) uji tabel anova hanya digunakan untuk menganalisis regresi berganda dengan menilai angka $F$ hitung 
menggambarkan layak atau tidak layaknya, regresi berganda tersebut dapat dianalisis dengan cara pembuktian hipotesis regresi berganda. Caranya membandingkan $F$ hitung dengan $F$ tabel, apabila $F$ hitung $>$ dari $F$ tabel maka regresi itu dianggap layak.

Hipotesisnya adalah:

$\mathrm{H}_{1}$ : Adanya hubungan linear yang signifikan antara kompetensi guru, budaya organisasi, dan pelayanan terhadap kepuasan.

$\mathrm{H}_{0}$ : Tidak ada hubungan linear yang signifikan antara kompetensi guru, budaya organisasi, dan pelayanan terhadap kepuasan.

Dalam penelitian ini, analisis uji $\mathrm{F}$ dilakukan dengan membandingkan nilai $F$ hitung dengan $F$ tabel dan dengan membandingkan nilai taraf signifikansi hitung dengan taraf signifikansi sebesar 0,05.

Dari hasil tabel anova di atas didapat nilai $F$ hitung sebesar 39.736, maka dengan mencari nilai pada tabel $F$, dengan $\mathrm{dbR}=3$ dan $\mathrm{dbG}=69$ didapat nilai $F$ tabel sebesar 2.74. Karena $F$ hitung lebih besar dari $F$ tabel $[F$ hitung (39.736) > F tabel (2.74)], maka dapat disimpulkan terima $\mathrm{H}_{1}$ dan tolak $\mathrm{H}_{0}$ yang berarti ada hubungan yang linear antara kompetensi guru, budaya organisasi, dan pelayanan terhadap kepuasan. Adapun analisis dengan membandingkan taraf siginifikan hitung dengan nilai taraf signifikan sebesar 0,05 , dari tabel anova di atas diperoleh nilai taraf signifikan sebesar 0,000 yang lebih kecil dari taraf signifikan 0,050. Maka dapat disimpulkan terima $\mathrm{H}_{1}$ dan tolak $\mathrm{H}_{0}$ yang berarti ada hubungan yang signifikan antara kompetensi guru, budaya organisasi, dan pelayanan terhadap kepuasan.

\section{Uji T}

Uji $\mathrm{T}$ dilakukan untuk mengetahui berapa besar variabel bebas (independen) secara individual atau secara sendiri-sendiri dalam menerangkan variasi variabel terikat (dependen).

\section{Tabel 4. Hasil Uji T}

Coefficients $^{\mathrm{a}}$

\begin{tabular}{|c|c|c|c|c|c|c|}
\hline & \multirow[b]{2}{*}{ Model } & \multicolumn{2}{|c|}{$\begin{array}{l}\text { Unstandardized } \\
\text { Coefficients }\end{array}$} & \multirow{2}{*}{$\begin{array}{c}\text { Standardized } \\
\text { Coefficients } \\
\text { Beta }\end{array}$} & \multirow[b]{2}{*}{$t$} & \multirow[b]{2}{*}{ Sig. } \\
\hline & & $B$ & Std. Error & & & \\
\hline 1 & (Constant) & .563 & .250 & & 2.256 & .027 \\
\hline
\end{tabular}

Jurnal Manajemen Pendidikan Islam, Volume.I, Nomor.1, Januari 2018 


\begin{tabular}{c|r|r|r|r|r|}
\hline Kopetensi Guru & .376 & .110 & .430 & 3.420 & .001 \\
Budaya Organisasi & .292 & .163 & .273 & 1.788 & .078 \\
Pelayanan & .153 & .143 & .148 & 1.069 & .289 \\
\hline
\end{tabular}

a. Dependent Variable: Kepuasan

Hasil yang diperoleh dari tabel di atas adalah:

a) Pengaruh variabel Kompetensi Guru terhadap Kepuasan

$\mathrm{H}_{1}$ : ada hubungan linear yang signifikan antara kompetensi guru dengan kepuasan.

$\mathrm{H}_{0}$ : tidak ada hubungan linear yang signifikan antara kompetensi guru dengan kepuasan.

Dengan melihat tabel $\mathrm{t}$ di atas diperoleh nilai signifikan untuk variabel kompetensi guru terhadap kepuasan sebesar 0,001 lebih kecil dari taraf signifikan sebesar 0,05 maka dapat disimpulkan terima $\mathrm{H}_{1}$ dan tolak $\mathrm{H}_{0}$, hal ini berarti bahwa ada hubungan linear yang signifikan antara kompetensi guru dengan kepuasan. Adapun besarnya pengaruh kompetensi guru dengan kepuasan sebesar 0,430 (yang diambil dari nilai beta).

b) Pengaruh variabel Budaya Organisasi terhadap Kepuasan

$\mathrm{H}_{1}$ : ada hubungan linear yang signifikan antara budaya organisasi dengan kepuasan.

$\mathrm{H}_{0}$ : tidak ada hubungan linear yang signifikan antara budaya organisasi dengan kepuasan.

Dengan melihat tabel $\mathrm{t}$ di atas diperoleh nilai signifikan untuk variabel budaya organisasi terhadap kepuasan sebesar 0,078 lebih besar dari taraf signifikan sebesar 0,05 maka dapat disimpulkan terima $\mathrm{H}_{0}$ dan tolak $\mathrm{H}_{1}$, hal ini berarti bahwa tidak ada hubungan linear yang signifikan antara budaya organisasi dengan kepuasan. Adapun besarnya pengaruh budaya organisasi dengan kepuasan sebesar 0,273 (yang diambil dari nilai beta).

c) Pengaruh Variabel Pelayanan terhadap Kepuasan

$\mathrm{H} 1$ : ada hubungan linear yang signifikan antara pelayanan dengan kepuasan.

$\mathrm{HO}$ : tidak ada hubungan linear yang signifikan antara pelayanan dengan kepuasan. 
Dengan melihat tabel $\mathrm{t}$ di atas diperoleh nilai signifikan untuk variabel pelayanan terhadap kepuasan sebesar 0,289 lebih besar dari taraf signifikan sebesar 0,05, maka dapat disimpulkan terima $\mathrm{H}_{0}$ dan tolak $\mathrm{H}_{1}$, hal ini berarti bahwa tidak ada hubungan linear yang signifikan antara pelayanan dengan kepuasan. Adapun besarnya pengaruh pelayanan dengan kepuasan sebesar 0,148 (yang diambil dari nilai beta).

Nilai error pada persamaan struktur ini adalah:

$$
\begin{aligned}
€ & =1-R^{2} \\
& =1-0,633 \\
& =0,367
\end{aligned}
$$

Maka berdasarkan hasil analisis jalur ini persamaan strukturnya menjadi :

$$
Y=0,430 X_{1}+0,273 X_{2}+0,148 X_{3}+0,367 €
$$

\section{Uji Normalitas}

Uji asumsi normalitas dilakukan untuk mengetahui apakah model mempunyai distribusi normal atau tidak. Uji normalitas mempunyai tujuan untuk menguji apakah dalam model regresi ini, variabel pengganggu (residual) memiliki distribusi normal atau tidak. Dari hasil analisa regresi didapati hasil sebagai berikut :

Gambar 5. Grafik Histogram

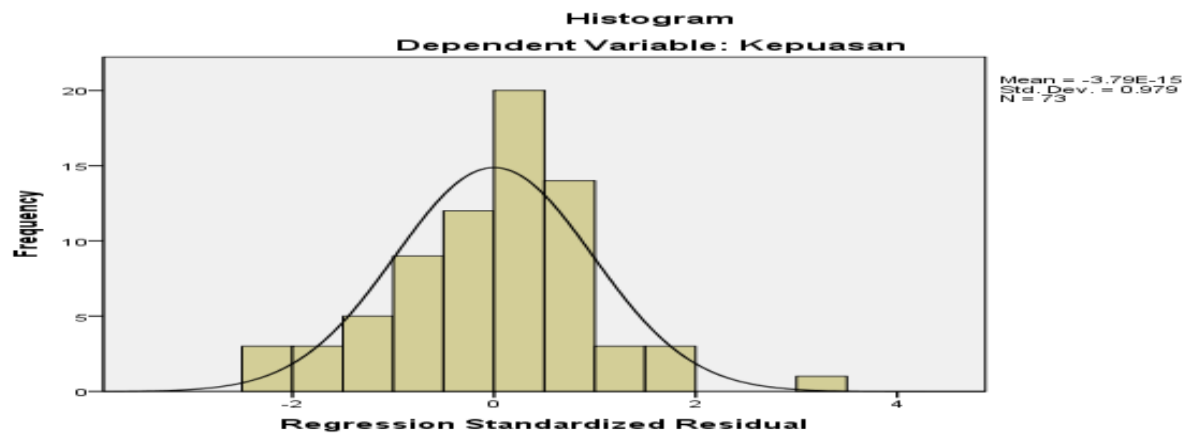

Melihat gambar grafik histogram di atas, maka dapat ditarik kesimpulan bahwa ketika grafik histogram membentuk kurva bel, maka dengan demikian data dianggap berdistribusi normal.

\section{Uji Linearitas}

Untuk mengetahui bahwa model yang dibangun mempunyai hubungan linearitas atau tidak maka dilakukan uji linearitas. Uji linieritas yang 
dipergunakan adalah P-Plot grafik di mana asumsi linieritas terpenuhi jika titik-titik pada grafik mendekati sumbu diagonalnya. Hasil analisis regresi didapati gambar P-Plot Diagram sebagai berikut :

Gambar 6. P-Plot Diagram

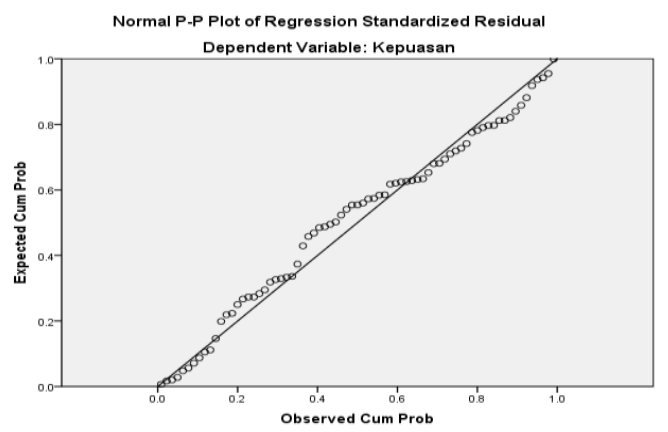

Dari gambar di atas dapat disimpulkan data sudah membentuk garis lurus dari sisi kiri bawah ke kanan atas sesuai dengan teori linieritas, sehingga dapat disimpulkan bahwa linieritas dalam model regresi ini sudah dipenuhi.

\section{Uji Heteroskedastisitas}

Agar dapat mengetahui ada atau tidaknya heteroskedastisitas dengan melihat gambar P-Plot antara nilai prediksi variabel terikan (dependen) yaitu ZPRED dengan residualnya SRESID. Uji heteroskedastisitas dapat dilakukan dengan melihat ada tidaknya pola tertentu pada gambar Scatter Plot antara SRESID dan ZPRED, di mana sumbu $Y$ adalah $Y$ yang diprediksi, dan sumbu $\mathrm{X}$ adalah residual. Dasar analisisnya dapat dijabarkan sebagai berikut:

a) Jika ada pola tertentu, seperti titik-titik yang ada membentuk pola tertentu yang teratur (bergelombang, melebar kemudian menyempit), maka mengindikasikan telah terjadi heteroskedastisitas.

b) Jika ada pola yang jelas, serta titik-titik menyebar di atas dan di bawah angka 0 pada sumbu $Y$, maka tidak terjadi heteroskedastisitas.

Berdasarkan gambar Scatter Plot hasil olah dari regresi didapati gambar sebagai berikut: 


\section{Gambar 7 Scatter Plot}

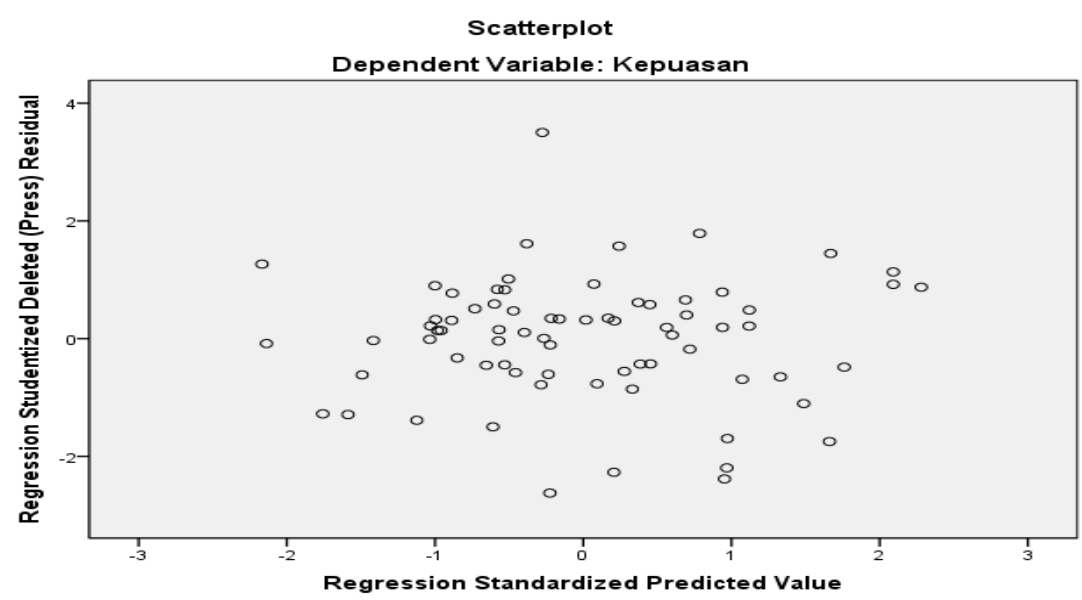

Dapat dilihat dari gambar diagram di atas bahwa model dalam penelitian ini tidak mempunyai gangguan heteroskedastisitas, karena tidak ada pola tertentu pada gambar grafik scatter plot tersebut. Titik-titik pada grafik relatif menyebar baik di atas sumbu nol maupun di bawah sumbu nol pada sumbu $\mathrm{Y}$.

\section{Analisa Korelasi Antar Variabel Kompetensi Guru, Budaya Organisasi, Pelayanan, dan Kepuasan OrangTua Murid Pada SMA Islam HASMI}

Korelasi koefisien antar variabel kompetensi guru, budaya organisasi, pelayanan, dan kepuasan dapat dilihat dari tabel berikut:

Tabel 5. Koefisien Korelasi Antar Variabel

Correlations

\begin{tabular}{|c|c|c|c|c|c|}
\hline & & Kepuasan & $\begin{array}{l}\text { Kopetensi } \\
\text { Guru }\end{array}$ & $\begin{array}{c}\text { Budaya } \\
\text { Organisasi }\end{array}$ & Pelayanan \\
\hline \multirow{4}{*}{$\begin{array}{l}\text { Pearson } \\
\text { Correlation }\end{array}$} & Kepuasan & 1.000 & .760 & .742 & .701 \\
\hline & $\begin{array}{l}\text { Kompetensi } \\
\text { Guru }\end{array}$ & .760 & 1.000 & .802 & .753 \\
\hline & $\begin{array}{c}\text { Budaya } \\
\text { Organisasi }\end{array}$ & .742 & .802 & 1.000 & .840 \\
\hline & Pelayanan & .701 & .753 & .840 & 1.000 \\
\hline \multirow[t]{5}{*}{ Sig. (1-tailed) } & Kepuasan & & .000 & .000 & .000 \\
\hline & Kopetensi Guru & .000 & & .000 & .000 \\
\hline & Budaya & .000 & .000 & & .000 \\
\hline & Organisasi & & & & \\
\hline & Pelayanan & .000 & .000 & .000 & \\
\hline \multirow[t]{4}{*}{$\mathrm{N}$} & Kepuasan & 73 & 73 & 73 & 73 \\
\hline & Kopetensi Guru & 73 & 73 & 73 & 73 \\
\hline & $\begin{array}{c}\text { Budaya } \\
\text { Organisasi }\end{array}$ & 73 & 73 & 73 & 73 \\
\hline & Pelayanan & 73 & 73 & 73 & 73 \\
\hline
\end{tabular}

Untuk menginterpretasi nilai koefisien digunakan kriteria sebagai berikut : 
$0 \quad$ : Tidak ada korelasi antar dua variabel

$>0-0,25:$ Korelasi sangat lemah

$>0,25-0,5$ : Korelasi cukup

$>0,5-0,75$ : Korelasi kuat

$>0,75-0,9$ : Korelasi sangat Kuat

Dari tabel di atas dapat ditarik kesimpulan sebagai berikut:

(1) Adanya korelasi yang sangat kuat sebesar 0,802 dan searah antara Kompetensi Guru $\left(\mathrm{X}_{1}\right)$ dengan Budaya organisasi $\left(\mathrm{X}_{2}\right)$. Artinya jika variabel kompetensi guru nilainya tinggi maka variabel budaya organisasi juga dinilai tinggi dan berlaku sebaliknya. Korelasi dua variabel tersebut bersifat signifikan karena angka singnifikansinya sebesar 0,000 berarti lebi kecil dari 0,050 $(0,000<0,050)$.

(2) Adanya korelasi yang sangat kuat sebesar 0,753 dan searah antara Kompetensi Guru $\left(\mathrm{X}_{1}\right)$ dengan Pelayanan $\left(\mathrm{X}_{3}\right)$. Artinya jika variabel kompetensi guru nilainya tinggi maka variabel pelayanan juga dinilai tinggi dan berlaku sebaliknya. Korelasi dua variabel tersebut bersifat signifikan karena angka singnifikansinya sebesar 0,000 berarti lebi kecil dari 0,050 $(0,000<0,050)$.

(3) Adanya korelasi yang sangat kuat sebesar 0,760 dan searah antara Kompetensi Guru $\left(\mathrm{X}_{1}\right)$ dengan Kepuasan OrangTua $(\mathrm{Y})$. Artinya jika variabel kompetensi guru nilainya tinggi maka variabel kepuasan orangtua juga dinilai tinggi dan berlaku sebaliknya. Korelasi dua variabel tersebut bersifat signifikan karena angka singnifikansinya sebesar 0,000 berarti lebi kecil dari 0,050 $(0,000<0,050)$.

(4) Adanya korelasi yang sangat kuat sebesar 0,840 dan searah antara Budaya Organisasi $\left(X_{2}\right)$ dengan Pelayanan $\left(X_{3}\right)$. Artinya jika variabel budaya organisasi nilainya tinggi maka variabel pelayanan juga dinilai tinggi dan berlaku sebaliknya. Korelasi dua variabel tersebut bersifat signifikan karena angka singnifikansinya sebesar 0,000 berarti lebi kecil dari 0,050 $(0,000<0,050)$.

(5) Adanya korelasi yang kuat sebesar 0,742 dan searah antara Budaya Organisasi $\left(\mathrm{X}_{2}\right)$ dengan Kepuasan OrangTua $(\mathrm{Y})$. Artinya jika variabel budaya organisasi nilainya tinggi maka variabel kepuasan orangtua 
juga dinilai tinggi dan berlaku sebaliknya. Korelasi dua variabel tersebut bersifat signifikan karena angka singnifikansinya sebesar 0,000 berarti lebi kecil dari 0,050 $(0,000<0,050)$.

(6) Adanya korelasi yang kuat sebesar 0,701 dan searah antara Pelayan $\left(\mathrm{X}_{3}\right)$ dan Kepuasan OrangTua $(\mathrm{Y})$. Artinya jika variabel pelayanan nilainya tinggi maka variabel kepuasan orang tua juga dinilai tinggi dan berlaku sebaliknya. Korelasi dua variabel tersebut bersifat signifikan karena angka singnifikansinya sebesar 0,000 berarti lebi kecil dari 0,050 $(0,000<0,050)$.

Berdasarkan hasil analisis dan perhitungan di atas, maka akan didapati diagram jalur sebagai berikut.

Gambar 10 Diagram Jalur Hasil Analisa Hitung

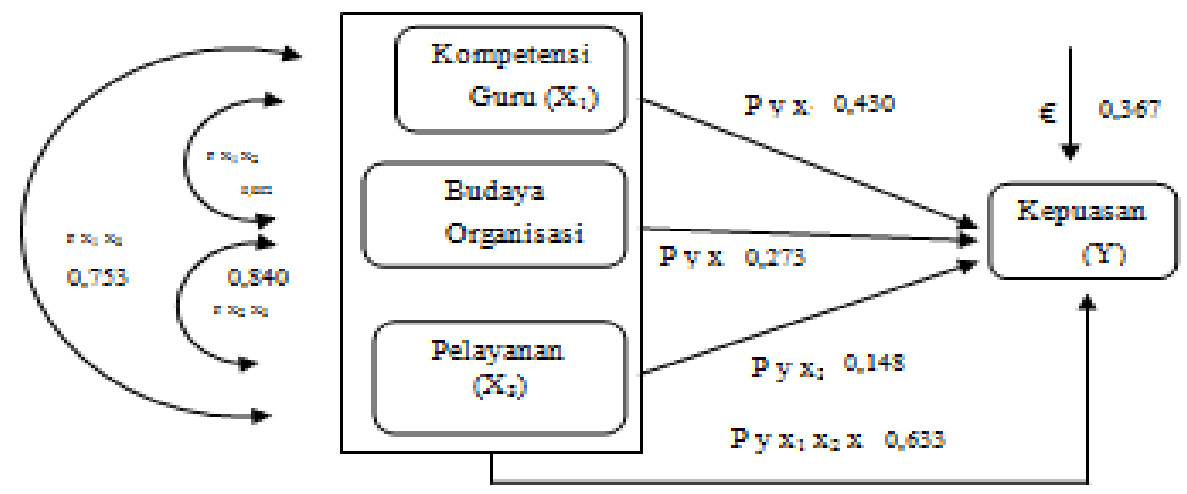

Persamaan Struktur :

$$
\begin{aligned}
& Y=P_{y x 1} X_{1}+P_{y x 2} X_{2}+P_{y x 3} X_{3}+P_{y} € \\
& Y=0,430 X_{1}+0,273 X_{2}+0,148 X_{3}+0,36 €
\end{aligned}
$$

\section{SIMPULAN}

Berdasarkan analisis data dengan menggunakan model path analysis (analisis jalur) terhadap penelitian tentang pengaruh kompetensi guru, budaya organisasi, dan pelayanan terhadap kepuasan orang tua murid pada SMA Islam HASMI, dapat ditarik kesimpulan yaitu adanya pengaruh variabel Kompetensi guru terhadap kepuasan orangTua Murid pada SMA Islam HASMI.

Berdasarkan analisis data yang menunjukkan hasil signifikan untuk variabel kompetensi guru terhadap kepuasan sebesar 0,001. Angka ini menunjukkan nilai signifikan yang lebih kecil dari taraf signifikan sebesar 
0,050. Kesimpulan dari hasil ini adalah terima $\mathrm{H}_{1}$ dan tolak $\mathrm{H}_{0}$, artinya ada hubungan linear dan signifikan antara kompetensi guru dengan kepuasan. Besarnya pengaruh kompetensi guru terhadap kepuasan sebesar 0,430. Semua ini menunjukkan bahwa kompetensi guru yang ada di SMA Islam HASMI berpengaruh positif dan nyata terhadap kepuasan orangtua murid.

Berdasarkan analisis data yang menunjukan hasil signifikan untuk variabel budaya organisai terhadap kepuasan sebesar 0,078. Angka ini menunjukkan nilai signifikan lebih besar dari taraf signifikan sebesar 0,050. Kesimpulan dari hasil ini adalah tolak $\mathrm{H}_{1}$ dan terima $\mathrm{H}_{0}$, artinya tidak ada hubungan linear yang signifikan antara budaya organisasi dengan kepuasan. Besarnya pengaruh budaya organisasi terhadap kepuasan sebesar 0,273. Semua ini menunjukkan bahwa budaya organisasi yang ada di SMA Islam HASMI tidak berpengaruh positif dan nyata terhadap kepuasan orang tua murid.

Tidak adanya pengaruh variabel pelayanan terhadap kepuasan OrangTua murid pada SMA Islam HASMI. Berdasarkan analisa data yang menunjukkan hasil signifikan untuk variabel pelayanan terhadap kepuasan sebesar 0,289. Angka ini menunjukkan nilai signifikan lebih besar dari taraf signifikan sebesar 0,050. Kesimpulan dari hasil ini adalah tolak $\mathrm{H}_{1}$ dan terima $\mathrm{H}_{0}$, artinya tidak ada hubungan linear yang signifikan antara pelayanan dengan kepuasan. Besarnya pengaruh pelayanan terhadap kepuasan sebesar 0,148 . Semua ini menunjukkan bahwa variabel pelayanan secara individu tidak berpengaruh positif dan nyata secara individual terhadap kepuasan orangtua murid.

Adanya pengaruh variabel kompetensi guru, budaya organisasi, dan pelayanan terhadap kepuasan orang tua murid Pada SMA Islam HASMI. Berdasarkan analisa data yang dilakukan pada penelitian ini diperoleh hasil bahwa variabel kompetensi guru, budaya organisasi, dan pelayanan secara simultan (bersama-sama) terhadap kepuasan orang tua murid pada SMA Islam HASMI sebesar 63,3 \%. Sedangkan sisanya sebesar 36,7 \% (100 \% $63,3 \%$ dipengaruhi oleh variabel lain di luar model ini. Angka ini menunjukkan bahwa variabel kompetensi guru, budaya organisasi, dan pelayanan secara bersama-sama mempunyai pengaruh yang positif dan 
nyata dalam menjelaskan kepuasan orangtua murid pada SMA Islam HASMI.

\section{DAFTAR PUSTAKA}

Arikunto, Suharsimi. (Edisi Revisi 2006). Prosedur Penelitian Suatu Pendekatan Praktik. Jakarta: Rineka Cipta.

(Edisi Revisi 2010). Prosedur Penelitian Suatu Pendekatan Praktik. Jakarta: Rineka Cipta.

Daryanto. (2013). Standard Kompetensi dan Penilaian Kinerja Guru Profesional. Yogyakarta: Gava Media.

Domonici, Gandolfo. (2010). Customer Satisfaction In The Hotel Industry: A Case Study From Sicily. (ijms International journal Of Marketing Studies Vol. 2, No. 2; November 2010). (Diunggah pada hari Senin, 08 Juli 2013 Pukul 13.50 WIB).

Ferdinand, Augusty. (2006). Metode Penelitian Manajemen. Edisi 2. Semarang: BP Universitas Diponegoro.

Hafidhudin, Didin \& Hendri Tanjung. (2003). Manajemen Syariah Dalam Praktik. Jakarta: Gema Insani.

Hamalik, Oemar. (2002). Pendidikan Guru; Berdasarkan Pendekatan Kompetensi. Jakarta: Bumi Aksara.

Hasibuan, Malayu S.P. (2005). Manajemen Sumber Daya Manusia. Jakarta:

PT Bumi Aksara.

Kartiko Widi, Restu (2010). Asas Metodologi Penelitian; Sebuah Pengenalan dan Penuntun Langkah demi Langkah Pelaksanaan Penelitian. Yogyakarta: Graha IImu.

Kirom, Bahrul. (2010). Mengukur Kinerja Pelayanan dan Kepuasan Konsumen. Bandung: Pustaka Reka Cipta.

Lupiyoadi, Rambat \& A. Hamdani (2011). Manajemen Pemasaran Jasa. Jakarta: Salemba Empat.

Mangkunegara, Anwar Prabu. (2008). Manajemen Sumber Daya Manusia Perusahaan. Bandung: PT. Remaja Rosdakarya.

Masyhudzulhak. (2012). Memahami Penulisan IImiah Dan Metode Penelitian.

LP2S Lembaga Pengkajian dan Pengembangan Sumber Daya. 
P, Darsono. (2009). Budaya Organisasi Kajian Organisasi Bisnis, ekonomi, Sosial, Pendidikan, dan Politik. Jakarta: Nusantara Consulting.

Payong, Marselus R. (2011). Sertifikasi Profesi Guru; Konsep Dasar, Problematika, dan Implementasinya. Jakarta: PT. Indeks

Priyatna, M. (2015). Implementasi Manajemen Pendidikan Berbasis Syariah di STAI Al-Hidayah Bogor. Jurnal Edukasi Islam, 4 (07), 787-805.

Priyatna, M. (2016). Manajemen Pengembangan SDM pada Lembaga Pendidikan Islam. Jurnal Edukasi Islam, 5 (09), 1231-1250.

Priyatna, M. (2016). Pendidikan Karakter Berbasis Kearifan Lokal. Jurnal Edukasi Islam, 5 (10), 1311-1336.

Priyanto, Agus. (2008). Jurnal Aplikasi Manajemen Volume 9 Nomor 3 Mei 2011. Faktor-faktor yang Mempengaruhi Kepuasan Orang Tua Siswa Terhadap Layanan Pendidikan di Sekolah. Terakreditasi SK Dirjen Dikti No. 43/DIKTI/KEP/2008. (Diunggah pada hari Senin, 08 Juli 2013 pukul $13.50 \mathrm{WIB})$.

Priyatno, Dwi. (2008). Mandiri Belajar SPSS (Statistical Product and Service Solution) Untuk Analisis Data \& Uji Statistik. Jakarta: Media Kom

Ridwan, (2004). Metode dan Teknik Menyusun Tesis. Alfabeta, Bandung.

Santoso, (2004). Buku Latihan SPSS Multivariate. Jakarta: Elek Media Komputindo.

Sugiyono. (2004). Metode Penelitian Bisnis. CV Alpabeta. Bandung

Supranto, J. (2011). Pengukuran Tingkat Kepuasan Pelanggan Untuk Menaikkan Pangsa Pasar. Jakarta: Rineka Cipta.

Supranto, J. \& Nandan Limakrisna. (2007). Perilaku Konsumen Dan Strategi Pemasaran Untuk Memenangkan Persaingan Bisnis. Jakarta: Mitra wacana Media.

Sobirin, Achmad. (2007). Budaya Organisasi; Pengertian, Makna dan Aplikasinya Dalam Kehidupan Organisasi. Yogyakarta: Unit Penerbit dan Percetakan Sekolah Tinggi IImu Manajemen YKPN.

Sumarwan, Ujang et al (2011). Riset Pemasaran dan Konsumen. Panduan Riset dan Kajian: Kepuasan, Perilaku Pembelian, Gaya Hidup, Loyalitas dan Persepsi Risiko. Bogor: IPB Press.

Tjiptono, Fandy. (2008). Strategi Pemasaran (Edisi III). Yogyakarta: Andi Offset. 
Wahidin, U. (2015). Efektivitas Model Pelatihan Komunikasi Pembelajaran Berbasis Multimedia Dalam Meningkatkan Kompetensi Mudarris. (Doctoral Dissertation, Universitas Pendidikan Indonesia).

Wibisono, Darmawan. (2006). Manajemen Kinerja; konsep, Desain, dan Tehnik Meningkatkan Daya Saing Perusahaan. Jakarta: Erlangga.

Wibowo. (2010). Budaya Organisasi; Sebuah Kebutuhan untuk Meningkatkan Kinerja Jangka Panjang. Jakarta: Rajawali Pers.

Wirawan. (2008). Budaya dan Iklim Organisasi; Teori Aplikasi dan Penelitian. Jakarta: Salemba Empat. 